\title{
Structure of Amino Acids Isolated from Hydrolyzed HV-Toxin M, a Host-specific Toxin-related Compound Produced by Helminthosporium victoriae ${ }^{\dagger}$
}

\author{
Yoshiki Kono, Takeshi Kinoshita, ${ }^{*}$ Setsuo Takeuchi \\ and J. M. DALY** \\ The Institute of Physical and Chemical Research, Wako-shi, \\ Saitama 351, Japan \\ * Analytical and Metabolic Research Lab., Sankyo Co., Ltd., \\ 2-58, Hiromachi l-chome, Shinagawa-ku, \\ Tokyo 140, Japan \\ ** University of Nebraska, Lincoln, Nebraska 68583-07I8, U.S.A.
}

Received September 16, 1988

\begin{abstract}
The chemistry of several of the specific toxins isolated from a culture medium of the phytopathogenic fungus Helminthosporium victoriae, a causal agent of Victoria blight disease of oat, was studied. The structures of the amino acid components of the isolated $H V$-toxin $M$ were identified, and the absolute configurations of the asymmetric $\alpha$-carbons were elucidated as $(S)(I \sim V$, Fig. 1$),(S)$ for C-3 of 3-OH-leucine (II), $(R)$ for C-3 of 3-OH-lysine (V) and ( $Z$ ) for 3-chlorodehydroalanine (VII).

The structure of the other toxin simultaneously isolated, $\mathrm{HV}$-toxin $\mathrm{H}$, was found to be identical with victorin $\mathrm{C}$.
\end{abstract}

The phytopathogenic fungus Helminthosporium victoriae, a causal agent of Victoria blight disease in a susceptible oat variety, produces host-specific damage to susceptible varieties. $^{1,2)}$ Recently, Macko et $a .^{2)}$ and Gloer et $a .^{3)}$ have reported structural studies on victorin $\mathrm{C}$, the major component of the hostspecific pathotoxin complex, in which its six structural components (five amino acids and glyoxylic acid) were identified, and also presented the primary structure of victorin $C^{4)}$ The chemical properties and structures of minor components of the toxin have also been reported. ${ }^{5)}$ In an independent study, we have isolated two host-specific toxinrelated compounds ( $\mathrm{HV}$-toxins $\mathrm{H}$ and $\mathrm{M}$ ) from a culture filtrate of $H$. victoriae. Five amino acid were isolated from the hydrolysate of Toxin $\mathrm{M}$ and their structures were elucidated, including the absolute configurations of some of its asymmetric carbon atoms, using HR-MS, NMR and ORD spectra (I V, Fig.

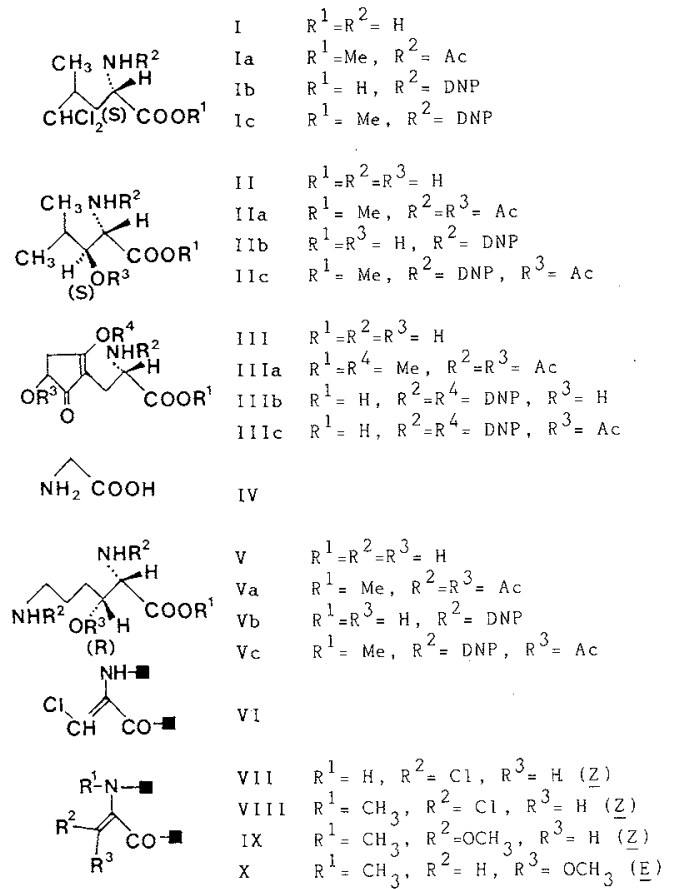

Fig. 1. Structures of Amino Acid Components of Toxin $M$ and Their Derivatives.

\footnotetext{
${ }^{\dagger}$ Part $\mathrm{I}$ in this series.
} 
1), as has been reported in a preliminary note. ${ }^{6)}$ In this paper, we describe details of the physical properties and the process for structural assignments of the amino acid components of Toxin $M$, and some additional properties of Toxin $H$. Details of the structural assignment of Toxin $\mathrm{M}$ using FAB-MS/MS ${ }^{7)}$ will be presented in a coming paper (Part II in this series).

\section{Results and Discussion}

Spores of $H$. victoriae were grown by still culture for two weeks at $20^{\circ} \mathrm{C}$ using Fries' medium supplemented with $1.5 \%$ oat flakes. Two toxins $\mathrm{H}$ and $\mathrm{M}$ were separated by $\mathrm{BuOH}$ extraction, repeated column chromatography on LH-20 and Shodex HW-40 columns, and preparative silica gel TLC, and were obtained as separate single spots (silica gel TLC, $\mathrm{BuOH}-\mathrm{AcOH}-\mathrm{H}_{2} \mathrm{O} 4: 1$ : 1; Toxin $\mathrm{H}$, Rf 0.28; Toxin $\mathrm{M}, R f 0.07$ ). Toxin $\mathrm{M}$ showed lower inhibitory activity in a dark $\mathrm{CO}_{2}$ fixation bioassay, and was obtained in a larger quantity $(5 \mathrm{mg} / \mathrm{l})$ than the more active Toxin $\mathrm{H}$ $(0.5 \mathrm{mg} / \mathrm{l})$.

Toxin $\mathbf{M}$ gave $(\mathrm{M}+\mathrm{H})^{+}$at $m / z 798$ from FAB-MS. The free amino groups in Toxin $M$ were selectively acetylated in $\mathrm{MeOH}$ with acetic anhydride, ${ }^{8)}$ and the products were separated by preparative silica gel TLC. The major component of the acetyl derivative of Toxin $M$ was analyzed by MS (FAB- and SI-MS) and NMR to show two $N$-acetyl groups in its NMR spectra, and gave $(\mathrm{M}+\mathrm{H})^{+}$at $m / z 882$ in its FAB- and SI-MS spectra. These results suggested the presence of two free amino groups in the Toxin $\mathrm{M}$ molecule. The UV spectrum showed $\lambda_{\max }(\mathrm{MeOH}) \mathrm{nm}(c): 244(18,000)$. The molecular formula for Toxin $M$ was found to be $\mathrm{C}_{31} \mathrm{H}_{46} \mathrm{~N}_{7} \mathrm{O}_{11} \mathrm{Cl}_{3}$ by HR-FAB-MS of the methylation product of the Toxin $\mathrm{M}$ diacetate (with $\mathrm{CH}_{2} \mathrm{~N}_{2}$, in $\mathrm{MeOH}$; corresponding to the conversion of VI to VIII in Fig. 1), which showed the molecular ion at $\mathrm{m} / \mathrm{z} 910.2894$ (calcd. 910.2923).

The isolated Toxin $\mathrm{M}$ diacetate was hydrolyzed with $2 \mathrm{~N} \mathrm{HCl}$ for $20 \mathrm{hr}$ at $110^{\circ} \mathrm{C}$. The hydrolysate was concentrated and separated on an Avicel column (BuOH-AcOH- $\mathrm{H}_{2} \mathrm{O}$, $4: 1: 5$, upper phase). Among the five amino acids isolated, I, II, III and $\mathbf{V}$ (Fig. 1) were found to be identical with those that have been isolated from a hydrolysate of victorin $\mathrm{C}^{2,3)}$ as was confirmed by HR-MS, NMR and FABMS/MS (a discussion of the results will appear in Part II in this series), and the remaining one was glycine (IV, Fig. 1), as was ascertained by TLC and NMR (see the experimental section for details).

The ${ }^{1} \mathrm{H}$ - and ${ }^{13} \mathrm{C}-\mathrm{NMR}$ spectra of the methylated product of the Toxin $\mathrm{M}$ diacetate (VIII in Fig. 1) showed two methyl groups incorporated in its molecule. NMR chemical shifts of one of them $\left(\delta_{\mathrm{H}}, 3.78 ; \delta_{\mathrm{C}}, 53.4\right)$ suggested that a free carboxylic acid group was methylated, and those of the other $\left(\delta_{\mathrm{H}}, 3.22\right.$; $\left.\delta_{\mathrm{C}}, 34.9\right)$, that one imino group was methylated (VIII, Fig. 1). The ${ }^{13} \mathrm{C}-\mathrm{NMR}$ spectrum spectrum included all 23 carbon signals expected from the five amino acid components isolated (I $\sim$ V, Fig. 1), but also contained a group of an ambiguous number of carbonyl carbon signals around $170 \mathrm{ppm}$. In addition to these signals, three extraneous signals considered to belong to unknown structural parts were observed at 134.2 (d), 138.0 (s) and $162.0 \mathrm{ppm}$ (s). The unsaturation degree of Toxin $\mathrm{M}$ based on its molecular formula is 11 , among which 8 is assigned to that of the five known components, and 2 is attributed to a carbonyl and an olefinic group indicated by the chemical shifts of the extraneous signals. The remaining one is explainable by assuming one cyclic function. The partial structure of the unknown part was therefore deduced to be VI (Fig. 1), identical with what had been observed earlier for victorin $\mathrm{C}^{2)}$ The molecular formula of Toxin $\mathrm{M}$ containing six amino acids was thus confirmed. The assignments of the sequence of these amino acid using FAB-MS/MS will be discussed in Part II in this series.

To estimate of the stereochemistry of the $\alpha$ carbon atoms of the four optically active amino acids, each of their 2,4-dinitrophenyl (DNP) derivatives was examined by ORD 
Table I. Comparison of ORD and CD Spectral Values for Optically active Amino ACID Components of Toxin M AFTer Conversion With DNP AND FOR Althentic SPECIMENS

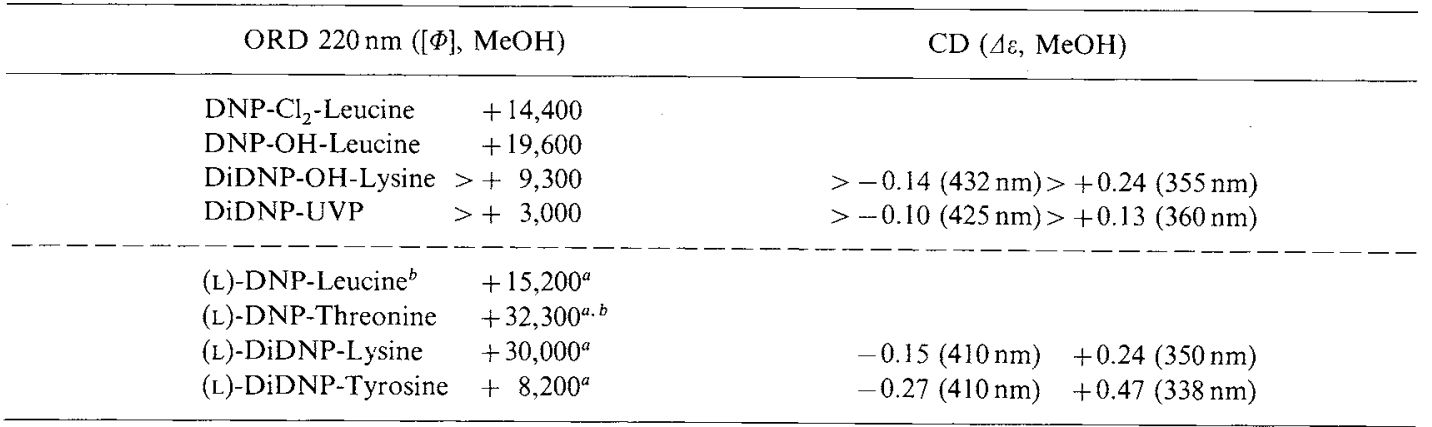

See ref. 9 .

${ }^{b}$ In $4 \% \mathrm{Na}_{2} \mathrm{CO}_{3}$.

Table II. COMParison of ChBmiCAL ShifTS for 3-Hydroxylysine AND 3-HYDROXYLEUCINE IN ${ }^{1} \mathrm{H}$-NMR (ppm/D $\left./ \mathrm{D}_{2} \mathrm{O}\right)$

\begin{tabular}{|c|c|c|c|c|c|c|c|}
\hline \multicolumn{3}{|c|}{ Origin } & \multirow{3}{*}{$\begin{array}{l}\mathrm{H}-2 \\
4.08 \\
4.06\end{array}$} & \multirow{3}{*}{$\begin{array}{l}\text { H-3 } \\
4.24 \\
4.22\end{array}$} & \multirow{3}{*}{$\begin{array}{l}\text { H-6 } \\
3.06 \\
3.05\end{array}$} & \multirow{3}{*}{\begin{tabular}{l}
\multicolumn{1}{c}{$\mathrm{H}-4,5$} \\
$1.5 \sim 2.0$ \\
$1.64 \sim 1.89$
\end{tabular}} & \multirow{3}{*}{$\begin{array}{r}\mathrm{OMe} \\
- \\
-\end{array}$} \\
\hline 3-OH-Lys & $\mathrm{COOH}$ & Victorin $\mathrm{C}^{u}$ & & & & & \\
\hline & & HV-Toxin $\mathrm{M}$ & & & & & \\
\hline & COOMe & erythro-DiHCl${ }^{b}$ & 4.10 & 3.94 & 2.90 & 1.67 & 3.70 \\
\hline & & Toxin $M(3 \mathrm{~N} \mathrm{DCl})$ & 4.26 & 4.32 & 3.13 & 1.80 & 3.77 \\
\hline & & threo-DiHCl ${ }^{b}$ & 4.32 & 4.25 & $(-)$ & 1.76 & 3.86 \\
\hline & & Toxin $\mathrm{M}\left(\mathrm{D}_{2} \mathrm{O}\right)$ & 3.65 & 4.04 & 3.05 & 1.74 & 3.74 \\
\hline \multirow{3}{*}{ 3-OH-Leu } & \multirow{3}{*}{$\mathrm{COOH}$} & & $\mathrm{H}-2$ & $\mathrm{H}-3$ & $\mathrm{H}-4$ & $\mathrm{H}-5,5^{\prime}$ & \\
\hline & & Victorin $C^{c}$ & 4.31 & 3.56 & 2.01 & $0.98 / 0.99$ & \\
\hline & & HV-Toxin M & 4.23 & 3.56 & 2.02 & $1.00 / 1.01$ & \\
\hline
\end{tabular}

a threo, see ref. 2.

b Synthesized, see ref. 12 .

c erythro, see ref. 2.

$(-)$, not reported.

[Table I; ORD spectral data of (L)-DNPleucine to (L)-diDNP-tyrosine were taken from Nagai et al. $\left.{ }^{9}\right)$. It is known that many L-amino acids, including those which contain an optically active $\beta$-carbon atom beside the active $\alpha$-carbon atom (e.g., L-threonine and Lisoleucine) exhibit a positve rotation in the same wavelength region. ${ }^{9}{ }^{\prime}$ It seems, therefore, fairly reasonable to assume that the polarity of rotation is in general not much affected by the presence of an additional asymmetry in the $\beta$ carbon atom, and hence an $(S)$-configuration was assigned to $\alpha$-carbon atoms of the opti- cally active components (I, II, III and V, Fig. 1) of Toxin $\mathrm{M}$. The stereochemistry of C-3 in the obtained 3-hydroxyleucine was elucidated as $(S)$-configuration, based on a comparison of $[\alpha]_{D}$ values [obsd., $[\alpha]_{D}^{26^{\circ}}=+15^{\circ}(c=0.22$, $\left.\mathrm{H}_{2} \mathrm{O}\right)$; authentic $(2 S, 3 S)$-3-hydroxyleucine, $[\alpha]_{\mathrm{D}}=+25^{\circ} \quad\left(c=1.05, \quad \mathrm{H}_{2} \mathrm{O}\right)^{10)} ; \quad(2 S, 3 R)-3-$ hydroxyleucine, $\left.[\alpha]_{D}=-3.5^{\circ}\left(c=2, \mathrm{H}_{2} \mathrm{O}\right)^{11)}\right]$, and NOE measurements of the methylated product of Toxin $\mathrm{M}$ diacetate (datails will be discussed in Part II) suggested an erythroconfiguration between $\mathrm{H}-2$ and $\mathrm{H}-3$, as with the case of victorin $\mathrm{C}$ (Table II). ${ }^{2,3)}$ The stereo- 
chemistry of C-3 in the obtained 3-hydroxylysine was elucidated as $(R)$ by comparing the ${ }^{1} \mathrm{H}$-NMR chemical shifts of the free amino acid and of its methylated dihydrochloride salt obtained from Toxin $M$ with threo-3-hydroxylysine methyl ester dihydrochloride obtained by synthesis ${ }^{12)}$ and threo-3-hydroxylysine obtained from victorin $\mathrm{C}^{2}{ }^{2)}$ The results of ${ }^{1} \mathrm{H}$-NMR spectra are summarized in Table II. ${ }^{2.12)}$ The stereochemistry of the exocyclic double bond in VI was estimated as $(Z)$-configuration, based on the following conjecture. Firstly, the chemical shift of its olefinic proton was in a fairly low field $\left(\delta_{\mathrm{H}} 7.68\right)$ and was closer to that of the $(E)$-3-chloro- $\left(\mathrm{H}-3, \delta_{\mathrm{H}}\right.$ 7.32) than to that of the $(Z)$-3-chloro-acrylic acids $\left(\mathrm{H}-3, \delta_{\mathrm{H}} 6.85\right) .{ }^{13)}$ Secondly, when compared to the olefinic proton signals of the $(Z)$ OMe and $(E)$-OMe derivatives of Toxin $\mathrm{M}\left(\delta_{\mathrm{H}}\right.$ 7.55 and 6.78 , respectively), it was closer to that of the $(Z)$-OMe compound.

An amino acid analysis of the acid hydrolysates of Toxin $\mathrm{M}$ gave five major peaks of amino acids with the following approximate retention times: $48 \mathrm{~min}$ (III; authentic aspartic acid, $50 \mathrm{~min}$ ), $100 \mathrm{~min}$ (IV; glycine), $131 \mathrm{~min}$ (II; valine, $129 \mathrm{~min}$ ), $185 \mathrm{~min}$ (I; glucosamine, $195 \mathrm{~min}$ ) and $222 \mathrm{~min}(\mathbf{V}$; ornithine, $227 \mathrm{~min})$.

A hydrolysate of Toxin $\mathrm{H}$ gave four amino acid peaks having respective retention times identical with those of III, II, I and V.

$\mathrm{N}$-acetylation of Toxin $\mathrm{H}$ gave the $\mathrm{N}$ monoacetylated Toxin $\mathrm{H}$, indicating the presence of one free amino group. The ${ }^{13} \mathrm{C}-\mathrm{NMR}$ spectrum of the $N$-acetyl derivative showed signals with close resemblance to those of victorin $C$; especially, the three signals due to the amino acid VI [at 128.7 (d), 133.0 (s) and $162.4 \mathrm{ppm}(\mathrm{s})]$, and one signal due to glyoxylic acid [at $94.3 \mathrm{ppm}$ (d)] suggested common amino acid constituents for Toxin $\mathrm{H}$ and victorin $\mathrm{C}$. Furthermore, the high biological activity of Toxin $\mathrm{H}$ also supported its identity as victorin $\mathrm{C}$.

Previously, we have isolated victoxinine- $\alpha$ glycerophosphate (VGP) ${ }^{14)}$ from low-activity cultures of $H$. victoriae in a medium without added oat flakes, ${ }^{15,16)}$ and considered this as a possible component of $\mathrm{HV}$-toxin, as has been earlier considered for victoxinine. ${ }^{17)}$ Actually, the acid hydrolysates of $\mathrm{HV}$-toxins $\mathrm{H}$ and $\mathrm{M}$ did not give these spots on TLC, and it was made clear that HV-toxins did not contain VGP or victoxinine as their constituent, even though both VGP and victoxinine were detected in the high-activity culture supplemented with oat flakes.

The biological activities of Toxin $\mathrm{M}$ and of Toxin $\mathrm{H}$ isolated along with $\mathrm{M}$ were preliminarily investigated by the dark $\mathrm{CO}_{2}$ fixation method. In this bioassay, Toxin $\mathrm{H}$ showed a $50 \%$ inhibition below $20 \mathrm{ng} / \mathrm{ml}$, and Toxin $\mathrm{M}$ showed a $50 \%$ inhibition at around $1 \sim 2 \mu \mathrm{g} / \mathrm{ml}$ on susceptible oat leaves, but no effect was observed on resistant oat leaves at a $1 \sim 2 \mu \mathrm{g} / \mathrm{ml}$ concentration. ${ }^{6)}$

Details of the structural assignments of Toxin $M$ will be presented and discussed in Part II of this series.

\section{Experimental}

Analytical methods. Standard analytical methods were carried out using the following instruments: JEOL HX100 for FAB-MS, FAB-MS/MS and HR-FAB-MS; Hitachi RMU-6M(G) for low-resolution MS, Hitachi M80 for high-resolution and FD-MS; and JEOL FX-90Q $(90 \mathrm{MHz}, 22.5 \mathrm{MHz})$ and JEOL FX- and GX-400 $(400 \mathrm{MHz})$ for ${ }^{1} \mathrm{H}$ - and ${ }^{13} \mathrm{C}-\mathrm{NMR}$. Perkin-Elmer Model$241 \mathrm{MC}$ polarimeter was used for $[\alpha]_{D}$ measurements, and Shimadzu IR-435 and Shimadzu UV-200 for IR and UV spectra. The amino acids analysis was carried out on a JEOL-6AH or Hitachi 835. Thin-layer chromatography was carried out on Merck silica gel $60 \mathrm{~F}_{254}(0.25$ or $0.5 \mathrm{~mm}$ thickness) or on Merck cellulose $F_{254}(0.1 \mathrm{~mm})$. The microcrystalline cellulose for column chromatography was Avicel (Funakoshi Pharm. Co., Ltd.).

Cultivation and isolation procedures. Spores of $H$. victoriae, which was suspended in $1 \%$ Triton X-100, were grown by still culture for two weeks at $20^{\circ} \mathrm{C}$ using Fries' medium supplemented with $1.5 \%$ oat flakes. Methanol (21) and $n-\mathrm{BuOH}$ (21) were added to the 51 culture filtrate (pH $3.2 \sim 3.4$ ) to precipitate insoluble materials originating from the oat flakes, which was then filtered off. The filtrate was concentrated in vacuo to approximately one liter, and extracted with $21 n$-BuOH three times. The extracts were combined and concentrated in vacuo to give about $12.3 \mathrm{~g}$ of crude materials. A portion $(2 \sim 3 \mathrm{~g})$ of the crude oily materials was dissolved in $40 \mathrm{ml}$ of methanol, and then 
subjected to gel filtration column chromatography (LH$20,5 \times 75 \mathrm{~cm}$ ) using methanol as a solvent. The earlier eluates, which were monitered by silica gel TLC using $n$ $\mathrm{BuOH}-\mathrm{AcOH}-\mathrm{H}_{2} \mathrm{O}(4: 1: 1)$ as the solvent, gave UVabsorbing spots at around 0.07 and 0.28 . The last spot had a slightly lower $R f$ than victoxinine- $\alpha$-glycerophosphate (VGP), which gave a blue spot by spraying $5 \%$ vanillin$95 \%$ conc. $\mathrm{H}_{2} \mathrm{SO}_{4}$ and heating. The eluate $(240 \mathrm{mg})$ was subjected to gel filtration column chromatography with a Shodex HW-50, using methanol as the solvent. The eluate ( $48 \mathrm{mg}$ ) was separated by preparative silica gel TLC using $n$-BuOH-AcOH- $\mathrm{H}_{2} \mathrm{O}(4: 1: 1$ or $4: 1: 2)$ as the solvent, and two spots were respectively eluted by the same solvent mixtures. Each of the eluates gave a single spot on silica gel TLC ( $\left.n-\mathrm{BuOH}-\mathrm{AcOH}-\mathrm{H}_{2} \mathrm{O}, 4: 1: 1\right)$, with $R f$ values of 0.28 (corresponding to Toxin $\mathrm{H}$ ) and 0.07 (Toxin $\mathrm{M}$ ). Each of the eluates of these spots was further purified by passing through a gel filtration $\mathrm{HW}-40$ column $(n-\mathrm{BuOH}-$ $\left.\mathrm{AcOH}-\mathrm{H}_{2} \mathrm{O}, 4: 1: 1\right)$, LH-20 (n-BuOH-AcOH$-\mathrm{H}_{2} \mathrm{O}$, $4: 1: 2)$ and $\mathrm{HW}-40\left(n-\mathrm{BuOH}-\mathrm{AcOH}-\mathrm{H}_{2} \mathrm{O}, 4: 1: 2\right)$, and finally gave purified samples of the toxins. The yields from one liter of culture filtrate were about $0.5 \mathrm{mg}$ of Toxin $\mathrm{H}$ and $5 \mathrm{mg}$ of Toxin $\mathrm{M}$.

${ }^{13} \mathrm{C}-\mathrm{NMR}$ spectrum $\left(22.5 \mathrm{MHz}, \mathrm{DMSO}-\mathrm{d}_{6}, \mathrm{ppm}\right)$ of $\mathrm{HV}$ toxin $M .15 .6(\mathrm{q}), 18.3(\mathrm{q}), 19.1(\mathrm{q}), 24.1(\mathrm{t}), 24.9(\mathrm{t}), 31.4$ (t), $33.3(\mathrm{~d}), 35.9(\mathrm{t} \times 2), 40.8(\mathrm{t} \times 2), 41.5(\mathrm{~d}), 50.4(\mathrm{~d}), 52.0$ (d), 55.2 (d), 59.6 (d), 71.0 (d), 71.5 (d), 81.0 (d), 86.3 (d), $114.3(\mathrm{~s}), 132.0(\mathrm{~d}), 143.3(\mathrm{~s}), 162.8(\mathrm{~s}), 173.0(\mathrm{~s}), 173,9(\mathrm{~s})$, $176.2(\mathrm{~s}), 185.2(\mathrm{~s})$ and $205.9(\mathrm{~s})$; two of the five carbonyl signals of amido groups overlapped with several signals between 173.0 to $176.2 \mathrm{ppm}$.

Acetylation of the free amino groups of $H V$-toxins $H$ and $M$. Each of the $\mathrm{HV}$-toxins $\mathrm{H}$ and $\mathrm{M}$ (approximately 1 to $2 \mathrm{mg}$ ) was dissolved in $4 \mathrm{ml}$ of $\mathrm{MeOH}$ to which had been added $1 \mathrm{ml}$ of acetic anhydride, and the solution was stirred at room temperature for four hours, before being kept at $4^{\circ} \mathrm{C}$ overnight and then concentrated in vacuo. Each of the $N$-acetylated toxins was purified by preparative silica gel TLC (n-BuOH-AcOH- $\left.\mathrm{H}_{2} \mathrm{O}, 4: \mathrm{I}: \mathrm{I}\right)$ and column chromatography with LH-20 (MeOH) and HW$40(\mathrm{MeOH})$. The $N$-acetylated Toxins $\mathrm{H}$ and $\mathrm{M}$ gave respective $\mathrm{UV}$-absorbing spots at $R f 0.40$ and 0.28 on silica gel TLC (Merck $F_{254}$ ) using the same solvent systems already described.

Properties of $N$-acetyl-HV-toxin $H$. UV $\lambda_{\max }(\mathrm{MeOH})$ $\mathrm{nm}(\varepsilon): 251 \quad(13,000) .{ }^{13} \mathrm{C}-\mathrm{NMR}\left(22.5 \mathrm{MHz}, \mathrm{CD}_{3} \mathrm{OD}\right)$ ppm: $14.2(\mathrm{q}), 18.0(\mathrm{q}), 19.5(\mathrm{q}), 22.6(\mathrm{q}, \mathrm{Ac}), 25.3(\mathrm{t}), 25.6$ $(\mathrm{t}), 30.0(\mathrm{~d}), 31.0(\mathrm{t}), 32.5(\mathrm{t}), 35.0(\mathrm{t}), 39.5(\mathrm{t}), 41.0(\mathrm{~d})$, 52.1 (d), 53.2 (d), 55.2 (d), 58.3 (d), 70.9 (d $\times 2), 79.3$ (d), 85.0 (d), 94.3 (d), 114.6 (s), 128.7 (d), $133.0(\mathrm{~s}), 162.4(\mathrm{~s})$, $169.4(\mathrm{~s}), 171.4(\mathrm{~s}), 172.4(\mathrm{~s}), 172.9(\mathrm{~s}), 176.8(\mathrm{~s}), 178.3(\mathrm{~s})$, $187.3(\mathrm{~s})$ and $206.8(\mathrm{~s})$.

Properties of $N, N^{\prime}$-diacetyl-HV-toxin $M$. FAB- and SI-
MS (glycerol): $(\mathrm{M}+\mathrm{H})^{+} m / z$ 882. FD-MS of Toxin M: $m / z 903$ (sodium salt). UV $\lambda_{\max }(\mathrm{MeOH}) \mathrm{nm}(\varepsilon): 244$ $(18,000) . \quad[\alpha]_{\mathrm{D}}^{22^{\circ}}=-25^{\circ} \quad(c=0.21, \quad \mathrm{MeOH}) . \quad$ IR $v_{\max }$ $\mathrm{cm}^{-1}$ (film): 3400, 3300, 2960, 1655, 1610, 1545, 1430, $1380,1310,1260,1111$ and $1080 .{ }^{13} \mathrm{C}-\mathrm{NMR}(22.5 \mathrm{MHz}$, $\left.\mathrm{CD}_{3} \mathrm{OD}\right)$ ppm: 14.2 (q), 18.5 (q), 19.9 (q), 22.4 (q, Ac), $22.5(\mathrm{q}, \mathrm{Ac}), 25.6(\mathrm{t}), 26.4(\mathrm{t}), 30.3(\mathrm{~d}), 31.7(\mathrm{t}), 33.1(\mathrm{t})$, $35.2(\mathrm{t}), 40.1$ (t), $41.5(\mathrm{~d}), 43.9(\mathrm{t}), 52.6(\mathrm{~d}), 53.7(\mathrm{~d})$, 55.7 (d), 59.3 (d), $71.5(\mathrm{~d} \times 2), 79.9$ (d), 85.0 (d), $114.6(\mathrm{~s})$, $128.7(\mathrm{~d}), 133.0(\mathrm{~s}), 163.0(\mathrm{~s}), 169.9(\mathrm{~s}), 170.9(\mathrm{~s}), 171.9(\mathrm{~s})$, $172.8(\mathrm{~s}), 173.9(\mathrm{~s}), 175.9(\mathrm{~s}), 186.3(\mathrm{~s})$ and $206.8(\mathrm{~s})$.

Isolation of amino acids from the acid hydrolysate of Toxin $M$ diacetate. Toxin $\mathrm{M}$ diacetate $(30 \mathrm{mg})$ was hydrolyzed with $2 \mathrm{~N} \mathrm{HCl}$ for $20 \mathrm{hr}$ at $120^{\circ} \mathrm{C}$. The hydrolysate was chromatographically separated using an Avicel column with $n$ - $\mathrm{BuOH}-\mathrm{AcOH}-\mathrm{H}_{2} \mathrm{O}$ (4:1:5, upper phase). The fractionated eluates were analyzed using cellulose TLC with $n-\mathrm{BuOH}-\mathrm{AcOH}-\mathrm{H}_{2} \mathrm{O}(4: 1: 2)$, and visualized by spraying ninhydrin solution. The fractions that gave common amino acid spots with respective $R f$ values were combined and concentrated in vacuo to give the five amino acids.

Identification of 5,5-dichloroleucine (I). The amino acid obtained from the first eluate of the Avicel column $(4.6 \mathrm{mg})$ showed a retention time of $185 \mathrm{~min}$ on an amino acid analyzer column, that of authentic glucosamine being $195 \mathrm{~min}$. $R f$ values on cellulose TLC were 0.80 and 0.84 when the developing solvent was $n-\mathrm{BuOH}-\mathrm{AcOH}-$ $\mathrm{H}_{2} \mathrm{O}, 4: 1: 1$ and $4: 1: 2$, respectively. SI-MS $m / z 200$ $\left[(\mathrm{M}+\mathrm{H})^{+}\right] \cdot{ }^{1} \mathrm{H}-\mathrm{NMR}\left(90 \mathrm{MHz}, \mathrm{D}_{2} \mathrm{O}, \mathrm{TSP}\right) \delta: 1.23(3 \mathrm{H}, \mathrm{d}$, $J=7 \mathrm{~Hz}), 2.20(2 \mathrm{H}, \mathrm{m}), 2.23(\mathrm{H}, \mathrm{m}), 4.18(\mathrm{H}, \mathrm{dd}, J=11$, $6 \mathrm{~Hz})$ and $6.11(\mathrm{H}, \mathrm{d}, J=3 \mathrm{~Hz}) .{ }^{13} \mathrm{C}-\mathrm{NMR}(22.5 \mathrm{MHz}$, $\left.\mathrm{D}_{2} \mathrm{O}, \mathrm{TSP}\right)$ ppm: $14.1(\mathrm{q}), 32.7(\mathrm{t}), 39.7$ (d), $51.0(\mathrm{~d}), 77.8$ (d) and 171.7 (s).

The amino acid was refluxed for $2 \mathrm{hr}$ in $\mathrm{MeOH}-\mathrm{SOCl}_{2}$ for methylation of its free carboxylic group. The methyl ester of the amino acid was acetylated ( $N$-acetate) with pyridine- $\mathrm{Ac}_{2} \mathrm{O}\left(2 \mathrm{ml} / 0.5 \mathrm{ml}, 4^{\circ} \mathrm{C}\right.$ overnight $)$. The solution was concentrated in vacuo to give an $\mathrm{N}$-acetyl-methyl ester (Ia) having the molecular formula $\mathrm{C}_{9} \mathrm{H}_{15} \mathrm{NO}_{3} \mathrm{Cl}_{2}$. HR-EIMS $m / z$ : obs. $256.0516\left[(\mathrm{M}+\mathrm{H})^{+},{ }^{35} \mathrm{Cl}\right]$, calcd. 256.0508 $\left({ }^{35} \mathrm{Cl}\right)$; and $m / z$ : obs. $258.0414\left({ }^{37} \mathrm{Cl}\right)$, calcd, 258.0477 $\left({ }^{37} \mathrm{Cl}\right)$. FD-MS $m / z: 256\left[(\mathrm{M}+\mathrm{H})^{+}\right]$. UV: end absorption. $[\alpha]_{\mathrm{D}}^{22^{\circ}}-19^{\circ}(c=0.14, \mathrm{MeOH})$. IR $v_{\max }(\mathrm{film}) \mathrm{cm}^{-1}: 3280$, $3060,2920,2840,1748,1658,1540,1439,1373,1265,1208$, $1154,1004,963,838,747$ and 695. ${ }^{1} \mathrm{H}-\mathrm{NMR}(400 \mathrm{MHz}$, $\mathrm{CDCl}_{3}$, TMS $) \delta: 1.22(3 \mathrm{H}, \mathrm{d}, J=7 \mathrm{~Hz}), 1.92(2 \mathrm{H}, \mathrm{m})$, $2.04(3 \mathrm{H}, \mathrm{s}, \mathrm{Ac}), 2.20(\mathrm{H}, \mathrm{m}), 3.76(3 \mathrm{H}, \mathrm{s}, \mathrm{OMe}), 4.72(\mathrm{H}$, $\left.\mathrm{m}, \mathrm{CH}-\mathrm{N} ;+\mathrm{D}_{2} \mathrm{O}: \mathrm{dd}, J=8,5 \mathrm{~Hz}\right), 5.80(\mathrm{H}, \mathrm{d}, J=3 \mathrm{~Hz})$ and $5.96\left(\mathrm{H}\right.$, br. $\mathrm{d}, J=8 \mathrm{~Hz} ;+\mathrm{D}_{2} \mathrm{O}$, exchangeable $){ }^{13} \mathrm{C}-$ NMR (22.5 MHz, CDCl${ }_{3}$ ) ppm: $15.2(\mathrm{q}), 22.8(\mathrm{q}, \mathrm{Ac}), 35.6$ $(\mathrm{t}), 41.0(\mathrm{~d}), 50.0(\mathrm{~d}), 52.2(\mathrm{q}, \mathrm{OMe}), 78.3(\mathrm{~d}), 170.0(\mathrm{~s})$ and 172.7 (s).

These data on the amino acid and its derivatives confirmed its structure as I (Fig. 1), 5,5-dichloroleucine. 
Identification of 3-hydroxyleucine (II). The structure of the amino acid in the second eluate from the Avicel column (5.5 mg) was identified as II (Fig. 1). Its retention time was approximately $131 \mathrm{~min}$ on the column of the amino acid analyzer (that of authentic valine was $129 \mathrm{~min}$ ). Its $R f$ values on TLC were 0.54 and 0.60 , respectively, using the two solvent systems described in the foregoing section. SI-MS (glycerol) $m / z: 148(\mathrm{M}+\mathrm{H})^{+} \cdot[\alpha]_{\mathrm{D}}^{22^{\circ}}+11^{\circ}$ $\left(c=0.22, \mathrm{H}_{2} \mathrm{O}\right) .{ }^{1} \mathrm{H}-\mathrm{NMR}\left(90 \mathrm{MHz}, \mathrm{D}_{2} \mathrm{O}, \mathrm{TSP}\right) \delta: 1.00$ $(3 \mathrm{H}, \mathrm{d}, J=7 \mathrm{~Hz}), 1.01(3 \mathrm{H}, \mathrm{d}, J=7 \mathrm{~Hz}), 2.02(\mathrm{H}, \mathrm{m}), 3.56$ $(\mathrm{H}, \mathrm{dd}, \mathrm{CH}-\mathrm{O})$ and $4.23(\mathrm{H}, \mathrm{d}, \mathrm{CH}-\mathrm{N}) .{ }^{13} \mathrm{C}-\mathrm{NMR}$ (22.5 MHz, $\left.\mathrm{D}_{2} \mathrm{O}, \mathrm{TSP}\right)$ ppm: 19.1 (q), 19.5 (q), 31.2 (d), $56.3(\mathrm{~d}, \mathrm{CH}-\underline{\mathrm{N}}), 77.0(\mathrm{~d}, \mathrm{CH}-\mathrm{O})$ and 170.5 (s, COO).

This amino acid was converted similarly to amino acid I, to give its $N, O$-diacetyl-methyl ester (IIa), molecular formula $\mathrm{C}_{11} \mathrm{H}_{19} \mathrm{NO}_{5}$. HR-EI-MS $m / z$ : obs. 246.1340 $\left[(\mathrm{M}+\mathrm{H})^{+}\right]$, calcd. 246.1311. UV: end absorption. $[\alpha]_{\mathrm{D}}^{22^{\circ}}-7^{\circ}(c=0.27, \mathrm{MeOH})$. IR $v_{\max }($ film $) \mathrm{cm}^{-1}: 3280$, $2960,2920,2850,1746,1660,1539,1435,1373,1239$ and 1025. ' $\mathrm{H}-\mathrm{NMR}\left(400 \mathrm{MHz}, \mathrm{CDCl}_{3}\right) \quad \delta: 0.94(3 \mathrm{H}, \mathrm{d}$, $J=7 \mathrm{~Hz}), 1.05(3 \mathrm{H}, \mathrm{d}, J=7 \mathrm{~Hz}), 2.01(3 \mathrm{H}, \mathrm{s}, \mathrm{Ac}), 2.07(3 \mathrm{H}$, $\mathrm{s}, \mathrm{Ac}), 2.14(\mathrm{H}, \mathrm{m}), 3.76(3 \mathrm{H}, \mathrm{s}, \mathrm{OMe}), 4.76(\mathrm{H}, \mathrm{dd}, J=8$, $3 \mathrm{~Hz}, \mathrm{CH}-\underline{\mathrm{O}}), 4.90(\mathrm{H}, \mathrm{dd}, J=7,3 \mathrm{~Hz}, \mathrm{CH}-\mathrm{N})$ and 6.38 (H, brd, NH). ${ }^{13} \mathrm{C}-\mathrm{NMR}\left(22.5 \mathrm{MHz}, \mathrm{CDCl}_{3}\right.$ ) ppm: 18.2 (q), 19.2 (q), 22.8 (q, Ac), 29.5 (d), 52.0 (q, OMe), 53.8 (d, $\mathrm{CH}-\mathrm{N}), 79.6(\mathrm{~d}, \mathrm{CH}-\mathrm{O})$ and $171.6(\mathrm{~s}, \mathrm{COO})$.

The data indicated the identity of this amino acid as II (Fig. 1), 3-hydroxyleucine.

Identification of 3-(2,4-oxy-5-oxo-1-cyclopenten-1-yl)alanine (III). The amino acid in the third eluate of the Avicel column showed a retention time of approximately $48 \mathrm{~min}$ (that of aspartic acid was $50 \mathrm{~min}$ ) on the amino acid analysis column. Its $R f$ values on TLC were 0.10 and 0.22 , respectively, using the foregoing two solvent systems. ${ }^{1} \mathrm{H}-$ NMR ( $\left.90 \mathrm{MHz}, \mathrm{D}_{2} \mathrm{O}, \mathrm{TSP}\right) \delta: 2.22(\mathrm{H}, \mathrm{dd}, J=18,2 \mathrm{~Hz})$, $2.80(\mathrm{H}, \mathrm{dd}, J=18,7 \mathrm{~Hz}), 2.62(2 \mathrm{H}, \mathrm{d}, J=6 \mathrm{~Hz}), 3.82(\mathrm{H}$, $\mathrm{m}, \mathrm{CH}-\mathrm{N})$ and $4.42(\mathrm{H}, \mathrm{m}, \mathrm{CH}-\mathrm{O}) .{ }^{13} \mathrm{C}-\mathrm{NMR}(22.5 \mathrm{MHz}$, $\left.\mathrm{D}_{2} \mathrm{O}, \mathrm{TSP}\right)$ ppm: $23.9(\mathrm{t}), 41.9(\mathrm{t}), 55.3(\mathrm{~d}, \mathrm{CH}-\mathrm{N}), 70.2(\mathrm{~d}$, $\mathrm{CH}-\mathrm{O}), 111.7$ (d), 174.9 (s), 201.2 (s) and 202.5 (s).

The amino acid was similarly converted to give its $N, \mathrm{O}^{\prime}$ diacetyl- $O$-methyl-methyl ester (IIla), molecular formula $\mathrm{C}_{14} \mathrm{H}_{19} \mathrm{NO}_{7}$. HR-EI-MS $m / z$ : obs. $313.1160\left(\mathrm{M}^{+}\right)$, calcd. 313.1122. UV $\lambda_{\text {max }}(\mathrm{MeOH}) \mathrm{nm}(\varepsilon): 254(6,200)$. IR $v_{\max }$ (film) $\mathrm{cm}^{-1}: 3300,2920,2850,1740,1660,1620,1535$, $1435,1372,1225,1175,1140,1085,1030$ and $960 .{ }^{1} \mathrm{H}-$ NMR $\left(400 \mathrm{MHz}, \mathrm{CDCl}_{3}\right) \delta: 1.98(3 \mathrm{H}, \mathrm{s}, \mathrm{Ac}), 2.14(3 \mathrm{H}, \mathrm{s}$, Ac), $2.60(\mathrm{H}, \mathrm{dd}, J=18,3 \mathrm{~Hz}), 2.64(2 \mathrm{H}, \mathrm{m}), 3.28(\mathrm{H}, \mathrm{dd}$, $J=18,6 \mathrm{~Hz}), 3.71(3 \mathrm{H}, \mathrm{s}, \mathrm{OMe}), 3.97(3 \mathrm{H}, \mathrm{s}, \mathrm{OMe}), 4.56$ $(\mathrm{H}, \mathrm{m}, \mathrm{CH}-\underline{\mathrm{N}})$ and $5.15(\mathrm{H}, \mathrm{dd}, J=6,3 \mathrm{~Hz}, \mathrm{CH}-\mathrm{O})$.

The data indicated the structure of this amino acid as III (Fig. 1).

Identification of glycine (IV). The amino acid in the fourth eluate of the Avicel column (3.8 $\mathrm{mg}$ ) was identified as glycine by an amino acid analysis (a retention time of $100 \mathrm{~min}$, agreeing with that of authentic glycine). Its $R f$ values were 0.14 and 0.25 , respectively, on TLC using the foregoing two solvent systems, identical with those of authentic glycine. ${ }^{1} \mathrm{H}-\mathrm{NMR}\left(90 \mathrm{MHz}, \mathrm{D}_{2} \mathrm{O}\right)$ gave a $2 \mathrm{H}$ singlet at $\delta 3.63$, identical with authentic glycine.

Identification of 3-hydroxylysine (V). The amino acid in the fifth eluate of the Avicel column $(4.4 \mathrm{mg})$. showed a retention time of approximately $222 \mathrm{~min}$ on the column of the amino acid analyzer (that of authentic ornithine was $227 \mathrm{~min}$ ). Its $R f$ values on TLC were 0.05 and 0.13 , respectively, using the foregoing two solvent systems. SIMS (glycerol) $m / z: 163(\mathrm{M}+\mathrm{H})^{+} .{ }^{1} \mathrm{H}-\mathrm{NMR}(400 \mathrm{MHz}$, $\left.\mathrm{D}_{2} \mathrm{O}, \mathrm{TSP}\right) \delta: 1.64(\mathrm{H}, \mathrm{m}), 1.76(2 \mathrm{H}, \mathrm{m}), 1.89(\mathrm{H}, \mathrm{m}), 3.05$ $\left(2 \mathrm{H}, \mathrm{m}, \mathrm{CH}_{2}-\mathrm{N}\right), 3.93(\mathrm{H}, \mathrm{d}, J=2 \mathrm{~Hz}, \mathrm{CH}-\mathrm{N})$ and $4.18(\mathrm{H}$, $\mathrm{m}, \mathrm{CH}-\mathrm{O}) .{ }^{13} \mathrm{C}-\mathrm{NMR}\left(22.5 \mathrm{MHz}, \mathrm{D}_{2} \mathrm{O}, \mathrm{TSP}\right) \mathrm{ppm}: 24.2$ $(\mathrm{t}), 30.9(\mathrm{t}), 40.3(\mathrm{t}), 58.8(\mathrm{~d}, \mathrm{CH}-\mathrm{N}), 69.3(\mathrm{~d}, \mathrm{CH}-\mathrm{O})$ and $171.3(\mathrm{~s}, \mathrm{COO})$

The amino acid was similarly converted to give its $N, N^{\prime}$ diacetyl- $O$-acetyl-methyl ester (Va), molecular formula $\mathrm{C}_{13} \mathrm{H}_{22} \mathrm{~N}_{2} \mathrm{O}_{6}$. HR-EI-MS $m / z$ : obs. $303.1565\left[(\mathrm{M}+\mathrm{H})^{+}\right]$, calcd, 303.1555. UV: end absorption. $[\alpha]_{\mathrm{D}}^{22^{\circ}}+42^{\circ}(c=0.28$, $\mathrm{MeOH})$. IR $v_{\max }(\mathrm{film}) \mathrm{cm}^{-1}: 3250,3040,2900,2840,1753$, $1645,1538,1425,1363,1280,1223,1142,1072,1040$ and 927. ${ }^{1} \mathrm{H}-\mathrm{NMR}\left(90 \mathrm{MHz}, \mathrm{CDCl}_{3}\right) \delta$ : around $1.60(4 \mathrm{H}, \mathrm{m})$, $1.96(3 \mathrm{H}, \mathrm{s}, \mathrm{Ac}), 2.03(3 \mathrm{H}, \mathrm{s}, \mathrm{Ac}), 2.11(3 \mathrm{H}, \mathrm{s}, \mathrm{Ac}), 3.72$ (3H, s, OMe), $4.84(\mathrm{H}, \mathrm{dd}, J=9,2 \mathrm{~Hz}, \mathrm{CH}-\mathrm{N}), 5.23(\mathrm{H}, \mathrm{m}$, $\mathrm{CH}-\mathrm{O}), 5.88(\mathrm{H}$, br. $\mathrm{t}, \varepsilon-\mathrm{NH})$ and $6.22(\mathrm{H}$, brd, $\alpha-\mathrm{NH})$. ${ }^{13} \mathrm{C}-\mathrm{NMR}\left(22.5 \mathrm{MHz}, \mathrm{CDCl}_{3}\right)$ ppm: 20.4 (q, Ac), 22.8 (q, $\mathrm{Ac}), 25.0(\mathrm{t}), 28.4(\mathrm{t}), 38.8(\mathrm{t}), 52.3(\mathrm{q}, \mathrm{OMe}), 53.7(\mathrm{~d}$, $\mathrm{CH}-\mathrm{N}$ ), 73.4 (d, CH-O), 169.3 (s) and 169.5 (s, COO).

The evidence indicated the identity of the amino acid as V (Fig. 1), 3-hydroxylysine.

Preparation of DNP (2,4-dinitrophenyl) derivatives of the amino acids. Approximately $2 \mathrm{mg}$ of each amino acid was dissolved in one $\mathrm{ml}$ of $5 \%$ aqueous sodium carbonate containing 10 to $20 \mathrm{mg}$ of FDNB (2,4-dinitro-1-fluorobenzene), and the solution was stirred for $30 \mathrm{~min}$ at $40^{\circ} \mathrm{C} .^{18)}$ Each amino acid solution was acidified with $6 \mathrm{~N}$ $\mathrm{HCl}$ and concentrated in vacuo. The DNP-derivative from each was purified with repeated preparative silica gel TLC, using $\mathrm{CHCl}_{3}-\mathrm{MeOH}-\mathrm{AcOH}(85: 15: 1), \mathrm{CHCl}_{3}-\mathrm{MeOH}-$ $\mathrm{AcOH}(95: 5: 1)$ and $\mathrm{CHCl}_{3}-\mathrm{MeOH}(96: 4)$ as solvents. Their $R f$ values with the solvent system of $\mathrm{CHCl}_{3}-\mathrm{MeOH}-$ AcOH $(85: 15: 1)$ were 0.63 for DNP-5,5-dichloroleucine (Ib), 0.45 for DNP-3-hydroxyleucine (IIb), 0.31 for $N, N^{\prime}$ diDNP-3-hydroxylysine (Vb), 0.08 for $N, O$-diDNP-III (IIIb), and 0.40 for DNP-glycine.

Properties of N-DNP-dichloroleucine (Ib). EI-MS of the methyl ester of $\mathbf{I b}(=\mathbf{I c})$ gave $\mathrm{m} / \mathrm{z}: 379\left(\mathbf{M}^{+}, 5 \%\right)$ and 320 $\left(\mathrm{M}^{+}-59,100 \%\right.$, above $\left.m / z 300\right)$. UV $i_{\text {max }}(\mathrm{MeOH}) \mathrm{nm}$ (c): 410 (shoulder), $351(14,200), 260(6,100)$ and 215 (10,200). ORD $(c=0.08, \mathrm{MeOH}) \cdot[\phi]^{22^{2}}(\mathrm{~nm}):+14,400$ (220). ${ }^{1} \mathrm{H}-\mathrm{NMR}\left(400 \mathrm{MHz}, \mathrm{CD}_{3} \mathrm{OD}, \mathrm{TMS}\right) \delta: 1.20(3 \mathrm{H}, \mathrm{d}$, $J=7 \mathrm{~Hz}), 1.99 / 2.22(1 \mathrm{H}$, each, $\mathrm{m}), 2.44(\mathrm{H}, \mathrm{m}), 4.27(\mathrm{H}$, dd, CH-N), 6.27 (H, d, CH- $\left.\mathrm{Cl}_{2}\right), 7.08$ (H, d, DNP's H-6), 
$8.28(\mathrm{H}, \mathrm{dd}, \mathrm{DNP}$ 's H-5) and $9.03(\mathrm{H}, \mathrm{d}, \mathrm{DNP}$ 's H-3)

Properties of N-DNP-3-hydroxyleucine (IIb). EI-MS of a further derivative (IIc) gave $m / z: 369\left(\mathrm{M}^{+}\right)$. UV $\lambda_{\max }$ $(\mathrm{MeOH}) \mathrm{nm}(\varepsilon): 417(\mathrm{sh}), 354(13,000), 260(6,100)$ and 216 $(8,800)$. ORD $(c=0.19, \mathrm{MeOH})[\phi]^{22^{c}}(\mathrm{~nm}):+19,600$ (220). ${ }^{1} \mathrm{H}-\mathrm{NMR}\left(400 \mathrm{MHz}, \mathrm{CD}_{3} \mathrm{OD}, \mathrm{TMS}\right) \delta: 1.03(3 \mathrm{H}, \mathrm{d}$, $J=7 \mathrm{~Hz}), 1.11(3 \mathrm{H}, \mathrm{d}, J=7 \mathrm{~Hz}), 2.00(\mathrm{H}, \mathrm{m}), 3.62(\mathrm{H}, \mathrm{dd}$, CH-O), 4.39 (H, d, CH-N), 7.13 (H, d, DNP's H-6), 8.25 (H, dd, DNP's H-5) and 9.03 (H, d, DNP's H-3).

Properties of $N, N^{\prime}$-diDNP-3-hydroxylysine (Vb). FDMS of a further derivative (Vc) gave $m / z: 550\left(\mathrm{M}^{+}, 100 \%\right)$ and $551\left[(\mathrm{M}+\mathrm{H})^{+}, 73 \%\right]$. UV $\lambda_{\max }(\mathrm{MeOH}) \mathrm{nm}(\varepsilon): 410$ $(\mathrm{sh}), 350(17,800), 260(8,700)$ and 212. ORD $(c=0.21$, $\mathrm{MeOH})[\phi]^{22^{\circ}}(\mathrm{nm}):+7,500(220) . \mathrm{CD}(c=0.21, \mathrm{MeOH}) \Delta$ $\varepsilon(\mathrm{nm}):-0.14(432)$ and $+0.42(355)$ [the CD spectrum of authentic $N, N^{\prime}$-diDNP-lysine $(c=0.16, \mathrm{MeOH}) \Delta \varepsilon(\mathrm{nm})$ : $-0.15(410)$ and $+0.24(350)]$. ${ }^{1} \mathrm{H}-\mathrm{NMR}(400 \mathrm{MHz}$, $\mathrm{CD}_{3} \mathrm{OD}$, TMS $\delta: 1.43 / 1.74(1 \mathrm{H}$ each $\mathrm{m}), 1.74 / 2.00(1 \mathrm{H}$ each, m) $3.51\left(2 \mathrm{H}, \mathrm{t}, \mathrm{CH}_{2}-\mathrm{N}\right), 4.20(2 \mathrm{H}, \mathrm{m}, \mathrm{CH}-\mathrm{O}$ and CH-N), 7.02/7.08 (1H, each, d/d, DNP's H-6 and H-6'), 8.22/8.25 ( $1 \mathrm{H}$ each, dd/dd, DNP's $\mathrm{H}-5$ and $\left.\mathrm{H}-5^{\prime}\right)$ and 9.05/9.07 (1H each, d/d, DNP's H-3 and H-3').

Properties of $O, N$-diDNP-III (=IIIb). FD-MS of a further derivative $\left(O^{\prime}\right.$-acetyl- $O, N$-diDNP-methyl ester, IIIc) gave $m / z: 590\left[(\mathrm{M}+\mathrm{H})^{+}, 2 \%\right]$ and $558[(\mathrm{M}+$ $\mathrm{H})^{+}-32,100 \%$. UV $\lambda_{\max }(\mathrm{MeOH}) \mathrm{nm}(\varepsilon): 410(\mathrm{sh})$, 353,265 and 212. ORD $(c=0.18, \mathrm{MeOH})[\phi]^{22^{\circ}}(\mathrm{nm})$ : $+3,000(220) . \mathrm{CD}(c=0.18, \mathrm{MeOH}) \triangle \varepsilon(\mathrm{nm}):-0.10(425)$ and $+0.13(360)$ [the CD spectrum of authentic diDNPtyrosine $(c=0.63, \mathrm{MeOH}) \Delta \varepsilon(\mathrm{nm}) ;-0.27$ (410) and +0.47 (338)]. ${ }^{1} \mathrm{H}-\mathrm{NMR}\left(400 \mathrm{MHz}, \mathrm{CD}_{3} \mathrm{OD}, \mathrm{TMS}\right) \delta$ : 2.23/3.21 (1 H each, dd, $\mathrm{CH}_{2}$ in cyclopetenone group), $2.78 \sim 2.87(2 \mathrm{H}, \mathrm{m}), 4.22(\mathrm{H}, \mathrm{CH}-\mathrm{N}), 4.50(\mathrm{H}, \mathrm{CH}-\mathrm{O})$, 7.10/7.15 (1H each, d/d, DNP's H-6 and H-6'), 8.27/8.29 (1H each, dd/dd, DNP's H-5 and H-5') and 9.04/9.05 (1H each, d/d, DNP's $\mathrm{H}-3$ and $\mathrm{H}-3^{\prime}$ ).

Acknowledgments. The authors thank Mr. Y. Esumi, Mr. M. Chijimatsu, Dr. J. Uzawa, Mrs. T. Chijimatsu and Dr. Tsuji of the Institute of Physical and Chemical Research for SI-, FD- and HR-EI-MS analyses, amino acid analyses, NMR analyses and advice on manuscript preparation, respectively. We thank $\mathrm{Mr}$. A. Kondo of Taisho Pharm. Co., Ltd. for NMR spectra. This work was supported in part by a Grant-in-Aid for Scientific Research from the Ministry of Education, Science and Culture of Japan

\section{References}

I) F. Meehan and H. C. Murphy, Science, 106, 270 (1947).

2) V. Macko, T. J. Wolpert, W. Acklin, B. Jaun, J. Seibl, J. Meili and D. Arigoni, Experientia, 41, 1366 (1985).

3) J. B. Gloer, J. Meinwald, J. D. Walton and E. D. Earle, Experientia, 41, 1370 (1985).

4) T. J. Wolpert, V. Macko, W. Acklin, B. Jaun, J. Seibl, J. Meili and D. Arigoni, Experientia, 41, 1524 (1985).

5) T. J. Wolpert, V. Macko, W. Acklin, B. Jaun and D. Arigoni, Experientia, 42, 1296 (1986).

6) Y. Kono, T. Kinoshita, S. Takeuchi and J. M. Daly, Agric. Biol. Chem., 50, 2689 (1986).

7) T. Nakamura, H. Nagaki and T. Kinoshita, Bull. Chem. Soc. Jpn., 58, 2798 (1985).

8) H. R. Morris, D. H. Williams and R. P. Ambler, Biochem. J., 125, 189 (1971).

9) U. Nagai, Y. Fujii, T. Umemura and M. Kurumi, "The Chemistry of Natural Products," 15, 1971, p. 55.

10) J. S. Davies, "Amino acids and Peptides," Chapman and Hall Ltd., 1985, p. 44

11) S. Dalby, G. W. Kenner and R. C. Sheppard, J. Chem. Soc., 1960, 968.

12) C. H. Stammer and R. G. Webb, J. Org. Chem., 34, 2306 (1969).

13) C. J. Pouchert and J. R. Campbell, "The Aldrich Library of NMR Spectra," 2, 1974, pp. 157 and 159.

14) Y. Kono, S. Takeuchi and J. M. Daly, Agric. Biol. Chem., 47, 2701 (1983).

15) R. B. Pringle and A. C. Braun, Phytopathology, 47, 369 (1957)

16) R. B. Pringle and A. C. Braun, Nature, 181, 1205 (1958).

17) F. Dorn and D. Arigoni, J. Chem. Soc., Chem. Commun., 1972, 1342.

18) J. Leggettbailey, "Techniques in Protein Chemistry," Elsevier Pub. Co., New York, 1967, p. 163. 